Jurnal Geocelebes Vol. 1 No. 2, Oktober 2017, 53 - 61

\title{
ANALISIS SEISMISITAS PADA DAERAH SULAWESI UTARA
}

\author{
Bambang Harimei S. , Muh. Altin Massinai, Mustakim \\ Laboratorium Geofisika Padat, Program Studi Geofisika, FMIPA Universitas Hasanuddin, Makassar
}

Penulis koresponden. Alamat email: bambang_harimei2004@yahoo.com

\begin{abstract}
Abstrak
Telah dilakukan penelitian tentang seismisitas daerah Sulawesi Utara. Penelitian bertujuan untuk menentukan nilai-a (seismisitas) dan nilai-b (kerapuan batuan) Data yang digunakan berasal dari aktivitas lempeng Sulawesi Utara dimulai dari tahun 1980 berakhir 2015. Metode yang digunakan dalam mencapai tujuan adalah maximum Likelihood dengan variabel nilai kerentanan batuan yang diberi lambang huruf $b$, nilai seismisitas yang diberi lambang a dan periode ulang $(T)$ dari magnitudo momen yang besarnya $6 \mathrm{SR}$ ke atas dengan lambang $\left(\mathrm{M}_{\mathrm{w}}\right)$. Adapun hasilnya nilai-a berkisar antara $5.5-9.5$, nilai-b berkisar antara $0.75-1.5$ dan periode ulang $(\mathrm{Mw}=6)$ berkisar $2-10$ Tahun, $(\mathrm{Mw}=$ 7) berkisar $10-60$ Tahun, $(\mathrm{Mw}=7.5)$ berkisar $35-150$ Tahun, $(\mathrm{Mw}=8)$ berkisar $95-360$ tahun.
\end{abstract}

Kata kunci: Nilai b, nilai a Maximum Likelihood, Periode ulang, Seismisitas

\begin{abstract}
A research on seismicity of North Sulawesi. The study aims to determine the value-a (seismicity) and $b$ value (fragility rock) data used comes from the activity of the plate to North Sulawesi began in 1980 ended 2015. The method used to achieve the goal is maximum likelihood rocks with variable susceptibility values by emblem letter $b$, the value of which was given the symbol of a seismicity and return period $(\mathrm{T})$ of the magnitude of moment magnitude $6 \mathrm{SR}$ upwards with the symbol $(\mathrm{Mw})$. The result-a value ranging between 5.5 and 9.5 , b values ranged between 0.75 and 1.5 and a return period $(\mathrm{Mw}=6)$ ranging from 2 to 10 years, $(\mathrm{Mw}=7)$ ranges from 10 to 60 years, $(\mathrm{Mw}=7.5)$ range 35 to 150 Year, $(\mathrm{Mw}=8)$ ranges from 95 to 360 years.
\end{abstract}

Keywords: $b$ value, the value of a maximum likelihood, period, seismicity

\section{Pendahuluan}

Pergerakan lempeng-lempeng mikro, maupun lempeng-lempeng utama yang ada di sekitar pulau Sulawesi. Pergerakan ini sebagai manifestasi dari tektonik yang dapat berdampak pada munculnya kawasan rawan bencana gempabumi (Ismullah et al., 2015). Bagian Sulawesi yang sangat rawan gempa salah satunya daerah Sulawesi Utara dengan koordinat
$00^{0} 15^{\prime} 51^{\prime \prime}-05^{0} 34^{\prime} 06^{\prime \prime}$ LU / 12307 $07^{\prime} 00^{\prime}$ $127^{0} 10$ '30" BT. Lokasi ini merupakan daerah dengan tingkat aktivitas gempabumi yang sangat tinggi. Hal ini dikarenakan daerah Sulawesi Utara dan sekitarnya terletak di antara batas-batas dan saling berinteraksi satu lempeng dengan lempeng lainnya, Interaksi ini mengakibatkan terbentuknya jalur subduksi dan sesar. 
Dengan menggunakan metode Lesat Square Ratih (2015) telah melakukan penetian tentang aktivitas lempeng tektonik di Sulawesi Tenggara, sebagai hasilnyan nilai-a berkisar antara 1,119037189 - 1,83792, nilai-b berkisar antara $-0,22391 \quad-\quad-0,1577$, indeks seismisitas berkisar antara 0,070341 0,301995, dan periode ulang berkisar antara 3,311311 - 14,425608 tahun.

Di samping itu, Lumintang dkk (2015) meneliti tentang Analisis Tingkat Seismisitas Dan Tingkat Kerapuhan Batuan Di Maluku Utara yang menghasilkan nilai-b berkisar pada 0,75 1,5 dan nilai-a adalah berkisar pada 6,5-10. Periode ulang gempa bumi untuk daerah Maluku Utara dengan magnitude $M w=6,5$ adalah 3-19 tahun, gempa dengan magnitude $M w=7$ adalah 5-52 tahun, dan gempa dengan magnitude $M w=7,5$ adalah 15-140 tahun.

\section{Metode Penelitian}

\section{Data}

Data yang digunakan dalam penelitian ini berupa data sekunder kejadian gempabumi dari koordinat $00^{0} 15^{\prime} 51^{\prime \prime}$ $05^{0} 34$ '06" LU / $123^{0} 07^{\prime} 00^{\prime \prime}$ - $127^{0} 10$ ' $30^{\prime \prime}$ BT dengan katalog USGS periode tahun 1980 - 2015 dengan batasan data magnitudo $(\mathrm{M}) \geq 4$ SR dan kedalaman (h) $\leq 100 \mathrm{~km}$ yang meliputi daerah Sulawesi Utara.

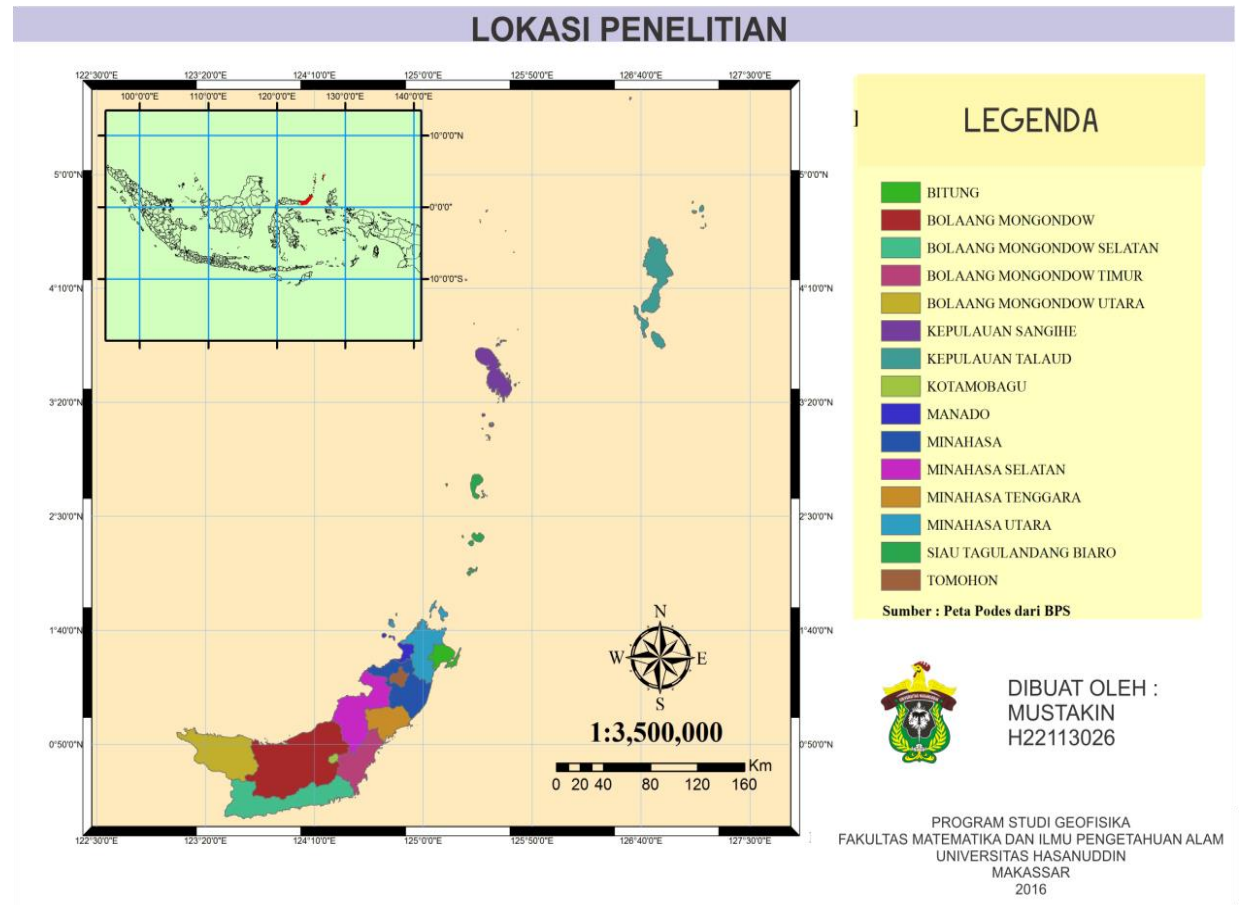

Gambar 1. Lokasi Penelitian

\section{Pengolahan Data}

Pengolahan data di Ms. Excel bertujuan merapikan data sekunder yang diperoleh dari katalog gempabumi USGS dan menyusun format tabel yang sesuai dengan pembacaan di software ZMAP. Format yang telah sesuai nantinya akan dicopy ke Notepad untuk di-save as dengan format file .dat

\section{Konversi Skala Magnitudo}

Gempa yang direkam pada katalog data gempa biasanya menggunakan skala magnitudo yang berbeda-beda, untuk itu perlu diseragamkan skala magnitudo tersebut kedalam Moment Magnitude $(M w)$, menggunakan Ms.Excel. 
Penyortiran Katalog Gempa (Declustering)

Proses penyortiran kalatog gempa bertujuan untuk memilah gempa utama terhadap gempa-gempa rintisan (foreshock) dan susulan (aftershock), sehingga didapat gempa yang independen menggunakan software ZMAP 6.0.

Nilai Magnitude Of Completeness (Mc), Nilai-a, Nilai-b, Dan Periode Ulang

Data yang terdiri dari longitude, latitude, tahun, bulan, hari, magnitude, kedalaman, jam, dan menit (kejadian gempabumi), diolah menggunakan software ZMAP 6.0 untuk menghitung nilai Mc (Magnitude Of Completeness), nilai-a (keaktifan seismik), nilai-b (kerapuhan batuan) dan periode ulang gempabumi.

Supaya nilai $b$ dan nilai a lebih akurat maka nilai $b$ dibuatkan cluster-cluster di dalam peta. Dalam hal ini, dibagi dua cluster. hal ini bertujuan untuk mempermudah dalam menganalisa Nilai-b. Cluster I meliputi $2,5^{0} \mathrm{LU}-5.159^{\circ} \mathrm{LU}$ dan $123.311^{0}$ BT $-127.024^{0}$ BT. Dan Cluster II meliputi $-0.022^{0}$ LS $-2.5^{0}$ LU dan $123.311^{0} \mathrm{BT}-127.024^{0} \mathrm{BT}$.

\section{Hasil dan Pembahasan}

\section{Distribusi Frekuensi Magnitudo Kurun Waktu 35 Tahun}

Distribusi frekuensi magnitudo menggambarkan distribusi katalog tentang hubungan magnitudo dan jumlah gempa yang terjadi. Parameter yang paling penting dalam menentukan nilai-a dan nilai-b adalah magnitudo of completeness (Mc).

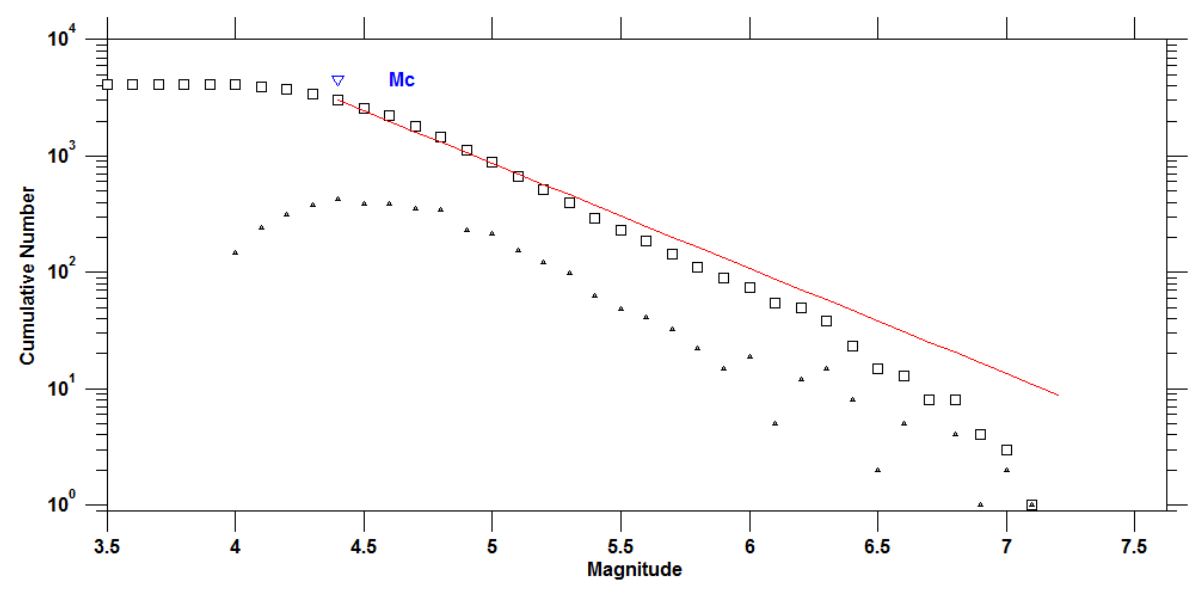

Maximum Likelihood Solution

b-value $=0.904+1-0.01$, a value $=7.46$, a value (annual $)=5.9$

Magnitude of Completeness $=4.4$

Gambar 2. Kurva Nilai b, Nilai a dan $M_{c}$

Dalam Gambar 2 menginformasikan bahwa Nilai Magnitudo of completeness (Mc) yaitu sebesar 4.4 SR nilai-b sebesar 0.904 , nilai-a sebesar 7,46 dengan bila dihitung secara manual sebesar 5,9. nilai-b yang rendah ini berarti tingkat kerapuan batuan daerah Sulawesi bagian Utara tergolong tinggi. Hal ini, dapat diartikan lempeng tektonik memiliki peluang terjadinya gempa-gempa besar. Sedang nilai-a mengidentifikasikan bahwa lempeng tektonik Sulawesi Utara memiliki tingkat keaktifan tinggi.

\section{Peta Variasi Spasial Nilai-b}

Pada Gambar 3 nilai-b berkisar antara 0.75 - 1.5. Hal ini menunjukkan bahwa daerah penelitian memiliki tingkat kerapuhan batuan tergolong tinggi. Dengan demikan lempeng tektonik di daerah ini memiliki peluang terjadinya aktivitas seismik dapat dikatakan tinggi. 


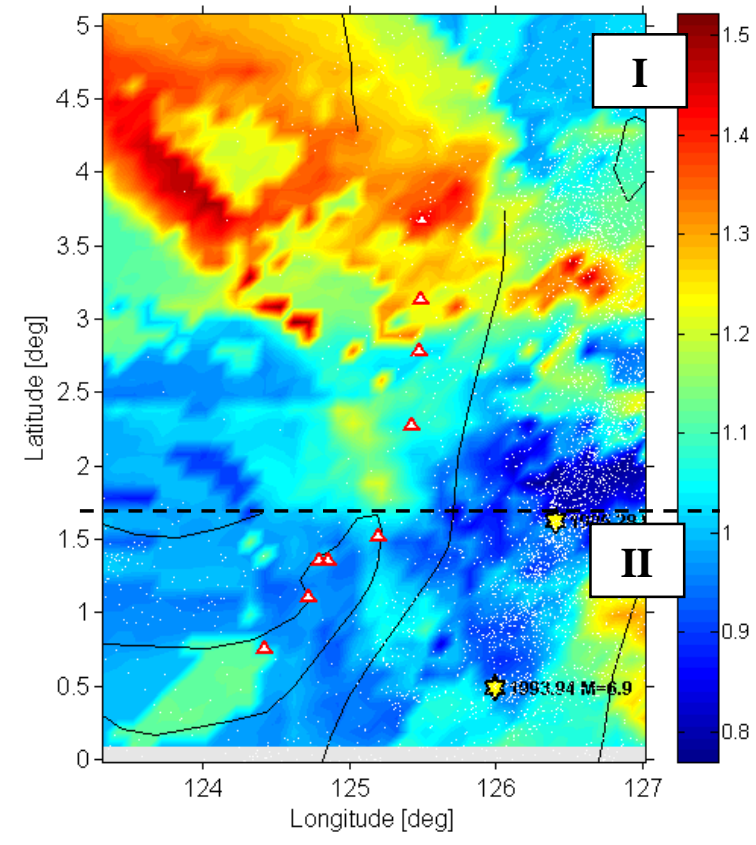

Gambar 3. Nilai-b Cluster I Dan Cluster II

Tabel 1. Nilai-b pada Cluster I dan Cluster II

\begin{tabular}{|c|c|l|}
\hline Cluster & Nilai-b & \multicolumn{1}{c|}{ Daerah } \\
\hline I & $\begin{array}{l}0.98- \\
1.5\end{array}$ & $\begin{array}{l}\text { Kep. Talaud dan } \\
\text { Kep. Sangihe. }\end{array}$ \\
\hline & & $\begin{array}{l}\text { Manado, Tomohon, } \\
\text { Bitung, Minahasa, } \\
\text { Minahasa Utara, } \\
\text { Minahasa Selatan } \\
\text { II }\end{array}$ \\
& $0.8-$ & $\begin{array}{l}\text { Minahasa Tenggara, } \\
\text { Bolaang } \\
\text { Mongondow, } \\
\text { Bolaang } \\
\text { Mongondow Selatan } \\
\text { dan Bolaang } \\
\text { Mongondow Timur. }\end{array}$ \\
\hline
\end{tabular}

Nilai-b yang tinggi terdapat pada cluster I sebesar $0.98-1.5$, meliputi daerah Kepulauan Talaud dan Kepulauan Sangihe. Hal ini disebabkan karena daerah tersebut merupakan jalur gunung api serta memiliki struktur yang rapuh kerana dilalui Sesar Sangihe, Palung Cotabato, Cekungan Sangihe dan Sesar Halmahera. Hal ini sesuai dengan peryataan oleh (Wandono, 2004), bahwa nilai b bergantung pada kondisi struktur, makin besar nilai $b$ menggambarkan struktur makin tidak homogen, pada daerah temperatur tinggi seperti dapur magma dan sumber geothermal menunjukkan nilai $b$ yang tinggi. Pada cluster I terdapat
Cekungan Celebes, yang terletak di daerah sebelah Barat Sulawesi Utara. Cekungan Celebes terletak dibatuan dasar cekungan berumur Eosen, dengan ketebalan sedimen 1000 - $2000 \mathrm{~m}$ pada kedalaman $2000 \mathrm{~m}$. Cekungan ini memiliki daerah terbuka yang mencapai $29.275 \mathrm{~km}^{2}$. Cekungan Celebes merupakan cekungan sedimen yang belum punya bukti adanya pembentukan migas (Suliantara dan Susantoro, 2013). hal ini menandakan bahwa pada daerah cluster I memiliki tingkat kerapuhan batuan (b-value) yang tinggi karena daerah tersebut didominasi oleh sedimen.

Nilai-b yang rendah terdapat pada cluster II sebesar 0.8 - 1.25, meliputi Manado, Tomohon, Bitung, Minahasa, Minahasa Utara, Minahasa Selatan, Minahasa Tenggara, Bolaang Mongondow, Bolaang Mongondow Selatan dan Bolaang Mongondow Timur. Hal ini dikarenakan daerah tersebut hanya dipengaruhi oleh sesar yang kurang aktif atau sesar yang lebih kecil seperti Sesar Manado, Sesar Bolmong dan Sesar Amurang.

Geologi daerah Sulawesi Utara (Cluster II) didominasi oleh batu gamping, sebagai satuan pembentuk cekungan sedimen Ratatotok (Somputan, 2012). Hal ini menandakan bahwa pada cluster II memiliki tingkat kerapuhan batuan (bvalue) yang rendah, karena batu gamping memiliki ketahanan yang kompak dan keras. akibatnya kondisi batuan di daerah tersebut tidak rapuh bila dibandingkan dengan cluster I.

Secara teori nilai-b merupakan parameter seismotektonik suatu daerah dimana terjadi gempabumi dan tergantung dari sifat batuan setempat dan berdasarkan hasil penelitian para ahli sebelumnya (Scholz, 1968) menyatakan bahwa nilai-b rendah berkorelasi dengan seismisitas rendah jika nilai-b tinggi maka tingkat seismitasnya tinggi. 
Selain itu, lempeng tektonik dengan heterogenitas yang besar berkorelasi dengan harga nilai-b yang tinggi (Mogi, 1962). Penelitian variasi spasial b-value telah di lakukan oleh para ahli di sejumlah daerah aktif gempa. Para ahli menyimpulkan bahwa b-value tidak bervariasi secara sistematis (konstan) dan diperkirakan nilainya berkisar sekitar 1.0. Tetapi Schorlemmer et all. (2004) dan Wesnousky et all. (1983) dan beberapa ahli lainnya menunjukkan bahwa b-value bervariasi secara signifikan di beberapa sesar aktif.

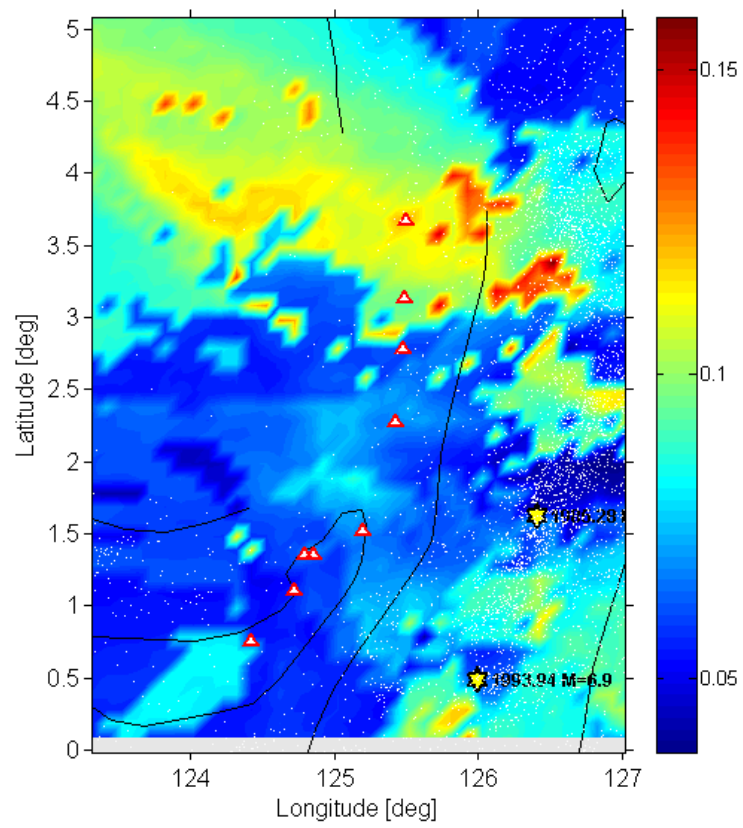

Gambar 4. Peta Variasi Spasial Standar Deviasi Nilai-b di daerah Sulawesi Bagian Utara

\section{Peta Variasi Spasial Nilai-a}

Distribusi spasial nilai-a (Gambar 5) tampak mirip dengan sebaran nilai-b. terlihat bahwa variasi nilai-a berada dalam kisaran 5.5 - 9.5. daerah penelitian dalam hal ini Sulawesi Bagian Utara dibagi kedalam II cluster. hal ini bertujuan untuk mempermudah dalam menganalisa sebaran nilai-a. Cluster I meliputi $2,5^{\circ} \mathrm{LU}-5.159^{\circ}$ LU dan $123.311^{0}$ BT $-127.024^{0}$ BT. Dan Cluster II meliputi $-0.022^{0} \mathrm{LS}-2.5^{0} \mathrm{LU}$ dan $123.311^{0}$ BT $-127.024^{0}$ BT.

Cluster I menghasilkan niila-a berkisar 7.3 - 9.5, meliputi daerah Kepulauan Talaud dan Kepulauan Sangihe. Cluster II menghasilkan nilai-a berkisar $5.5-8$, meliputi daerah Manado, Tomohon, Bitung, Minahasa, Minahasa Utara, Minahasa Selatan, Minahasa Tenggara, Bolaang Mongondow, Bolaang Mongondow Selatan dan Bolaang Mongondow Timur. Distribusi nilai-a yang tinggi terdapat pada cluster I. Nilai-a yang tinggi mengindikasikan daerah tersebut memiliki keaktifan seismik yang tinggi. Untuk distribusi nilai-a yang rendah terdapat pada cluster II. Nilai-a pada cluster II tidak setinggi pada cluster I. Hal ini menunjukkan daerah pada cluster II memiliki keaktifan seismik yang rendah dibandingkan dengan cluster I.

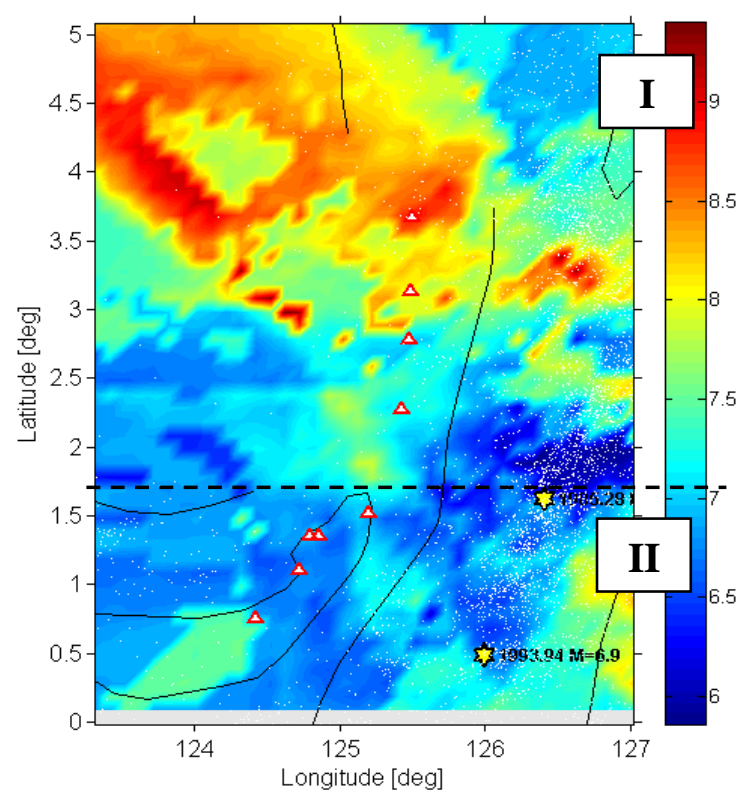

Gambar 5. Nilai-a Cluster I Dan Cluster II

Besaran nilai-a digunakan untuk menunjukkan tinggi rendahnya aktivitas seismik disuatu daerah, nilai ini selain bergantung pada jumlah event yang ada dalam batasan penelitian tersebut juga bergantung pada volume dan time window (Rohadi, dkk., 2007). Nilai-a dan Nilai-b yang rendah disuatu zona yang sama menunjukkan bahwa zona tersebut berpeluang terjadinya gempa besar diwaktu yang akan datang yang disebabkan oleh adanya akumulasi energi yang menimbulkan tingkat stress yang tinggi di zona tersebut. 
Daerah-daerah dengan nilai-a yang tinggi juga merupakan daerah-daerah dengan nilai-b yang tinngi. Hal ini serupa dengan pernyataan Rohadi (2009), yaitu pola distribusi nilai-b dan nilai-a memiliki kesesuaian dimana daerah dengan nilai-b yang tinggi bersesuaian dengan nilai-a yang tinggi.

\section{Periode Ulang Gempabumi}

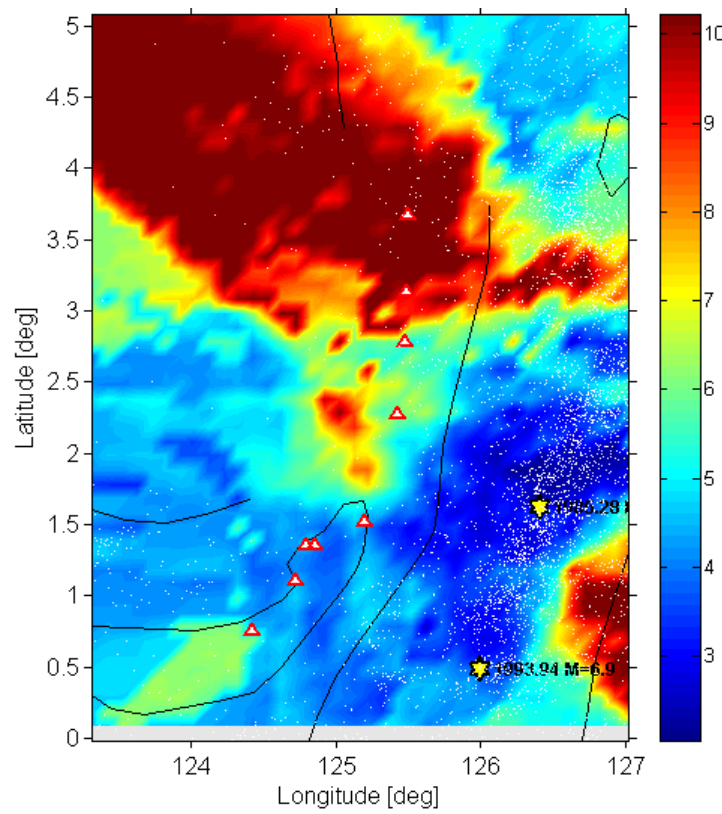

Gambar 6. Peta Variasi Spasial Periode Ulang dengan $\mathrm{Mw}=6 \mathrm{SR}$.

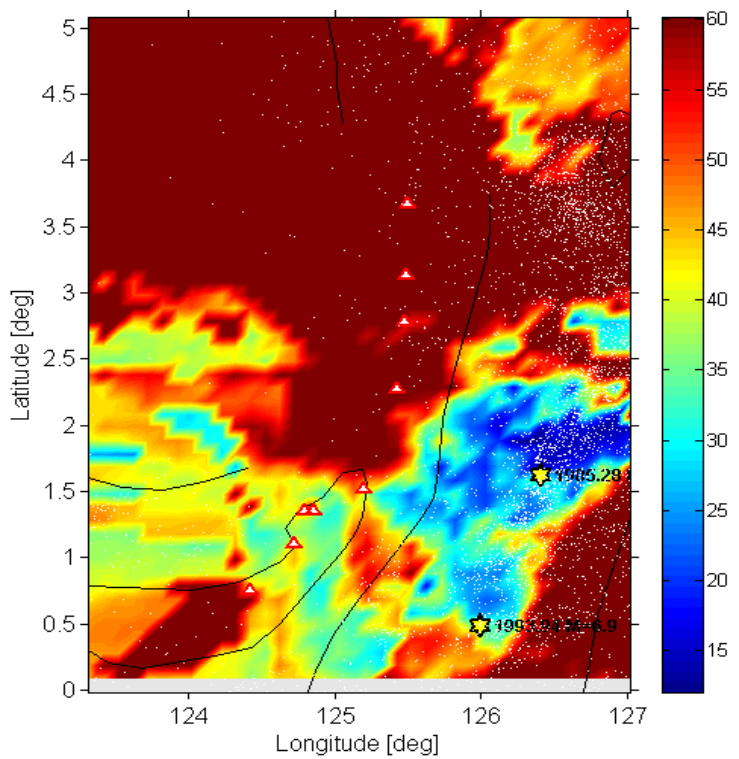

Gambar 7. Periode Ulang Dengan $\mathrm{Mw}=7 \mathrm{SR}$.

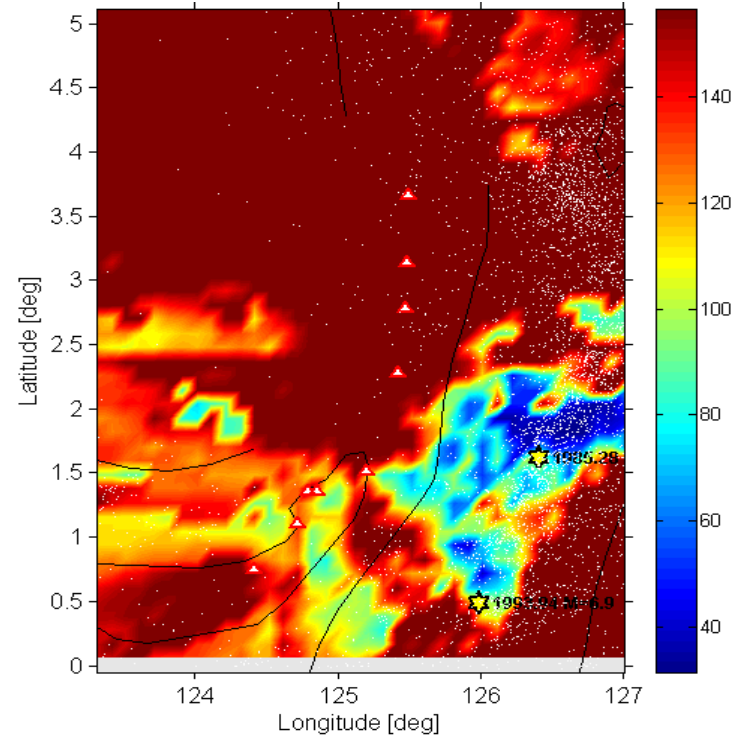

Gambar 8. Peta Variasi Spasial Periode Ulang dengan $\mathrm{Mw}=7.5 \mathrm{SR}$.

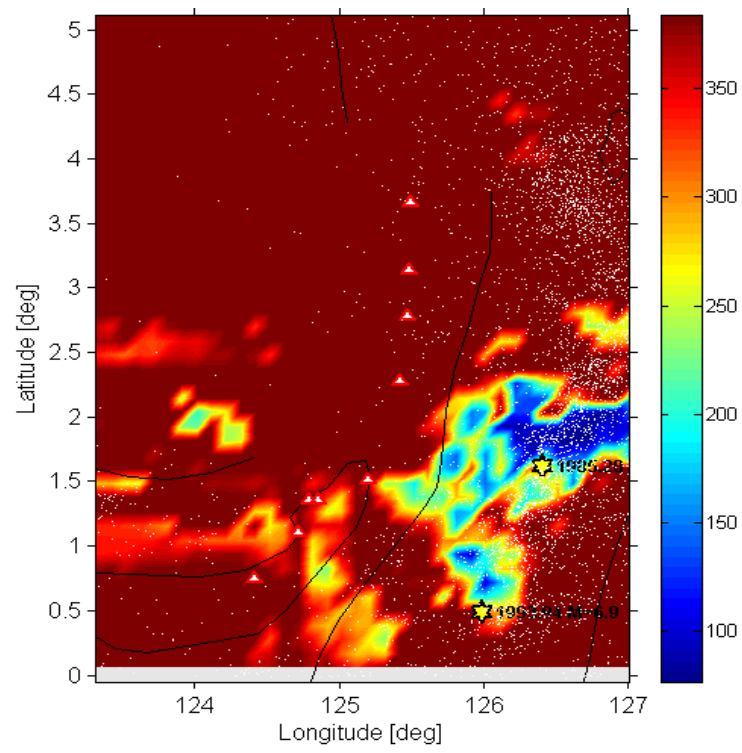

Gambar 9. Peta Variasi Spasial Periode Ulang Dengan $\mathrm{Mw}=8 \mathrm{SR}$

Dari hasil perhitungan periode ulang gempabumi (Gambar 6, 7, 8 dan 9), prediksi terjadinya gempa ulang dengan $\mathrm{Mw}=6, \mathrm{Mw}=7, \mathrm{Mw}=7.5$ dan $\mathrm{Mw}=8$.

Tabel 4.2 Periode Ulang Gempabumi

\begin{tabular}{|c|c|}
\hline Mw & Periode Ulang Gempabumi \\
\hline 6 & $2-10$ Tahun \\
\hline 7 & $10-60$ Tahun \\
\hline 7.5 & $35-150$ Tahun \\
\hline 8 & $95-360$ Tahun \\
\hline
\end{tabular}


Pada Gambar 6 tampak bahwa gempabumi dengan magnitudo 6 di daerah ini memiliki periode ulang yang berbeda beda yaitu sekitar 2- 10 Tahun. Periode ulang tercepat sekitar 3-5 Tahun meliputi daerah Manado, Tomohon, Bitung, Minahasa, Minahasa Utara, Minahasa Selatan, Minahasa Tenggara. Periode ulang dengan $\mathrm{Mw}=7$ pada Gambar 7 adalah 10 - 60 Tahun, Periode ulang tercepat terdapat pada daerah Manado, Tomohon, Minahasa, Minahasa Selatan, dan Minahasa Tenggara. Periode ulang dengan $\mathrm{Mw}=7.5($ Gambar 8) adalah $35-$ 150 Tahun, periode ulang tercepat terdapat pada daerah Tomohon, Minahasa, Minahasa Selatan dan Minahasa Tenggara dengan periode ulang sebesar 80 Tahun. Untuk periode ulang dengan $\mathrm{Mw}=8$
(Gambar 9) adalah 95 - 360 Tahun, daerah dengan periode ulang tercepat terdapat pada daerah Tomohon, Minahasa, dan Minahasa Tenggara dan Minahasa Selatan, dengan periode ulang sebesar 260 Tahun. Periode ulang yang pendek biasanya berkorelasi dengan nilai-b dan nilai-a yan rendah.

Daerah-daerah dengan periode ulang tercepat umumnya merupakan daerahdaerah dengan nilai-a dan nilai-b rendah, seperti daerah Manado, Tomohon, Bitung, Minahasa, Minahasa Utara, Minahasa Selatan, Minahasa Tenggara. Hal ini menunjukkan bahwa daerah-daerah tersebut lebih berpotensi untuk terjadinya gempa dengan magnitudo yang besar.

\section{Seismisitas di Daerah Sulawesi Bagian Utara.}

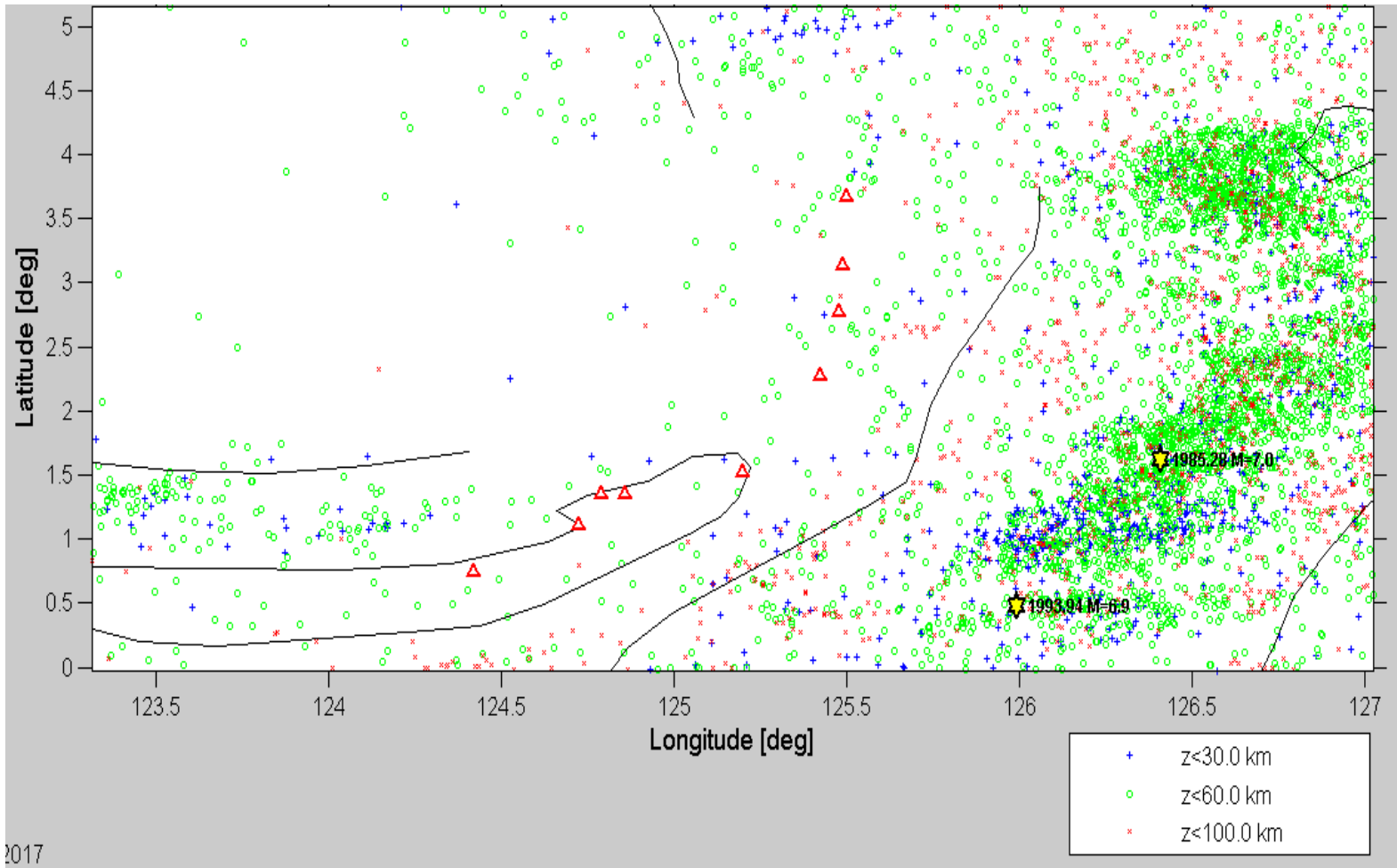

Gambar 10 Seismisitas lempeng tektonik Sulawesi Utara 
Daerah Sulawesi bagian Utara memiliki tingkat kegempaan yang sangat tinggi yang tersebar di laut dan di darat. Sumber gempabumi di daerah Sulawesi Utara terletak di laut akibat tumbukan antar busur kepulauan di sebelah Timur Sulawesi Utara dan Barat Halmahera yang menghasilkan penunjaman Punggungan Mayu, penunjaman Sulawesi Utara akibat adanya tumbukan antar busur vulkanik Sulawesi Utara dengan busur kepulauan dan sekumpulan sesar aktif di darat.

Pada bagian Timur Sulawesi Utara terbentuk suture Maluku yang terjadi akibat tumbukan ganda antara lempeng Laut Maluku dengan busur Halmahera dan Sangihe. Tumbukan tersebut diperkirakan terjadi pada kala Pliosen (Hall dan Wilson, 2000). Hal ini mengakibatkan terbentuknya Penunjaman Mayu yang masih aktif hingga kini, yaitu dicirikan dengan dengan tingkat kegempaan yang sangat tinggi.

Pada Gambar $\mathbf{1 0}$ terlihat bahwa gempabumi dengan kedalaman di bawah $60.0 \mathrm{~km}$ paling dominan terjadi. Tingkat seismisitas tertinggi terlihat di daerah sebelah Timur Sulawesi bagian Utara, hal ini dikarenakan adanya aktivitas penunjaman Punggungan Mayu yang menjadi sumber gempabumi di daerah Sulawesi.

\section{Kesimpulan dan Saran}

\section{Kesimpulan}

Berdasarkan analisis maka diperoleh kesimpulan sebagai berikut :

1. Nilai Magnitude of Completeness (Mc) di wilayah Sulawesi bagian Utara yaitu 4.4. Variasi spasial nilai-a di wilayah Sulawesi bagian Utara berkisar 5.5 - 9.5, wilayah dengan nilai-a tertinggi yaitu Kepulauan Talaud dan Kepulauan Sangihe. Variasi spasial nilai-b di wilayah Sulawesi Bagian Utara berkisar 0.75 -
1.5, wilayah dengan nilai-b tertinggi yaitu Kepulauan Talaud dan Kepulauan Sangihe. Periode ulang gempabumi dengan $\mathrm{Mw}=6$ adalah Berkisar $2-10$ Tahun, $\mathrm{Mw}=7$ adalah berkisar $10-60$ Tahun, $\mathrm{Mw}=$ 7.5 adalah berkisar 35 - 150 Tahun, $\mathrm{Mw}=8$ adalah berkisar 95- 360 Tahun.

2. Tingkat seismisitas tertinggi berada di bagian Timur wilayah Sulawesi Bagian Utara, hal ini disebabkan oleh aktivitas penunjaman Punggungan Mayu.

\section{Saran}

Perlu dilakukan penelitian lanjutan yaitu dengan mempertimbangkan faktor indeks seismisitas, probabilitas kejadian gempa bumi, dan diperlukan penelitian lebih lanjut terhadap wilayah dengan nilai $b$ yang rendah. Kerena wilayah dengan nilaib yang rendah memiliki peluang terjadinya gempa dengan magnitude yang besar.

\section{DAFTAR PUSTAKA}

Hall, R. and M.E.J. Wilson. 2000. Neogene Sutures in Eastern Indonesia. Journal of Asian Earth Sciences, 18, 781-808.

Ismullah, Muhammad Fawzy, Lantu, Aswad, Sabrianto, Massinai, Muh. Altin. 2015. Tectonics Earthquake Distribution Pattern Analysis Based Focal Mechanisms (Case Study Sulawesi Island, 1993-2012). AIP Conference Proceedings. Bandung.

Lumintang, Gaby, Pasau, Guntur, dan Tongkukut. 2015. Analisis Tingkat Seismisitas Dan Tingkat Kerapuhan Batuan Di Maluku Utara. Jurnal Ilmiah Sains Vol. 15 No. 2, Oktober 2015.

Mogi, K., 1962. Magnitude-frequency relationship for elactic shocks accompanying fractures of various materials and some related problem in earthquakes. Bull. Eartquake Res. Inst. Univ.Tokyo, 40:831-833 
Ratih, Dewi Astari. 2015. Analisis Seismisitas Dan Periode Ulang Gempabumi Wilayah Sulawesi Tenggara Berdasarkan B-Value Metode Least Square, Program Sarjana, Jurusan Fisika, Universitas Hasanuddin, Makassar.

Rohadi, Supriyanto. 2009. Distribusi Spasial dan Temporal Seismotektonik Wilayah Subduksi Jawa. Megasains 1(4):180-188

Rohadi, Supriyanto, Grandis, Hendra, dan Ratag, M.A. (2007) : Studi Variasi Spatial Seismisitas Zona Subduksi Jawa, Jurnal Meteorologi dan Geofisika, Vol.8 No.1

Schorlemmer, D., S. Wiemer, and M. Wyss., 2004, Earthquake Statistic at Parkfield: Stationary of b-Values, Journal of Geophysical Research, Vol. 109.

Scholz, C. H. 1968. The frequency magnitude relation of microfacturing in rock and its relation to earthquakes. Bull. Seismol. Soc. Am., 58:399-415.

Somputan, Amstrong F.2012.Struktur Geologi Sulawesi. Bandung: Institut Teknologi Bandung.

Suliantara, dan Susantoro, Trimuji. 2013. Pemetaan Cekungan Target Eksplorasi Migas Kawasan Timur Indonesia. Lembaran Publikasi Minyak dan Gas Bumi. Vol. 47 No.1, April 2013: 9 - 17.

Wesnousky, S.G., Scholz, C.H., Shimazaki, K., and Matsuda, T., 1983, EarthquakeFrequency Distribution and Mechanics of Faulting, Journal of Geophysical Research, Vol: 88, No. B11, P.93319340.

Wandono. 2004. Analisis Hubungan Frekuensi-Magnitudo Gempabumi Di Bali Dan Sekitarnya. Jurnal Matematika Dan Sains. 9(3): 273277 